Article

\title{
Hydraulic Parameter Generation Technique Using a Discrete Fracture Network with Bedrock Heterogeneity in Korea
}

\author{
Jae-Yeol Cheong ${ }^{1} \mathbb{C}$, Se-Yeong Hamm ${ }^{2, *}$, Doo-Hyun Lim $^{3}$ and Soo-Gin Kim ${ }^{1}$ \\ 1 Research \& Development Institute, Korea Radioactive Waste Agency, Daejeon 34129, Korea; \\ jjy@korad.or.kr (J.-Y.C.); point0410@korad.or.kr (S.-G.K.) \\ 2 Department of Geological Sciences, Pusan National University, Busan 46241, Korea \\ 3 FracMan Technology Group, Golder Associates Inc., Redmond, WA 98052, USA; \\ Doo-Hyun_Lim@golder.com \\ * Correspondence: hsy@pusan.ac.kr; Tel.: +82-51-510-2252
}

Received: 14 September 2017; Accepted: 28 November 2017; Published: 1 December 2017

\begin{abstract}
In instances of damage to engineered barriers containing nuclear waste material, surrounding bedrock is a natural barrier that retards radionuclide movement by way of adsorption and delay due to groundwater flow through highly tortuous fractured rock pathways. At the Gyeongju nuclear waste disposal site, groundwater mainly flows through granitic and sedimentary rock fractures. Therefore, to understand the nuclide migration path, it is necessary to understand discrete fracture networks based on heterogeneous fracture orientations, densities, and size characteristics. In this study, detailed heterogeneous fracture distribution, including the density and orientation of the fractures, was considered for a region that has undergone long periods of change from various geological activities at and around the Gyeongju site. A site-scale discrete fracture network (DFN) model was constructed taking into account: (i) regional fracture heterogeneity constrained by a multiple linear regression analysis of fracture intensity on faults and electrical resistivity; and (ii) the connectivity of conductive fractures having fracture hydraulic parameters, using transient flow simulation. Geometric and hydraulic heterogeneity of the DFN was upscaled into equivalent porous media for flow and transport simulation for a large-scale model.
\end{abstract}

Keywords: discrete fracture network; heterogeneity; fracture distribution; hydraulic parameter; upscaling

\section{Introduction}

In 2015, the Korea Radioactive Waste Agency at the Gyeongju nuclear waste facility started the first-stage of low- and intermediate-level radioactive waste disposal in a cavern at a depth of $130 \mathrm{~m}$ below the ground surface, and it is currently undergoing the process to gain permission from the regulatory agency in order to build a second-stage near-surface disposal facility. The Gyeongju radioactive waste disposal facility is equipped with a multi-barrier system consisting of a primary engineered barrier and secondary natural barrier in order to safely isolate nuclear waste from human exposure. The natural barrier functions to reduce the risk of radionuclide leakage from the disposal facility by adsorbing the radionuclides as well as impeding their movement, as the radionuclides predominately migrate along groundwater flow paths if the engineering barrier is damaged.

Radionuclide migration paths are intimately linked to discrete fracture networks that are characterized by heterogeneous fracture orientations, densities and sizes. Over the past several decades, the discrete fracture network (DFN) model has been utilized to characterize natural discrete fracture networks in relation to nuclear facilities [1-3], underground petroleum-storage systems [4,5], and enhanced geothermal systems [6,7]. The DFN model can simulate 2- or 3-dimensional networks 
of discrete features governing flow and transport, as well as partial or complete flow barriers or conductors (e.g., faults and argillaceous layers). It more accurately simulates the hydrodynamic behavior of fluids in fractured rocks by characterizing the distribution of faults and fractures $[1,5,8]$. DFN simulation successfully models this flow behavior by considering the connectivity, anisotropy, clusters and heterogeneity of the fractured rocks [9,10]. Swedish [11] and Finnish [12] regulating agencies have approved repository sites of high-level nuclear waste based on the evaluation of nuclide transport by using the DFN approach. A DFN generated using the feature rejection algorithm was used for simulating subsurface flow and transport [13]. Fractal DFN models were developed to simulate naturally fractured reservoirs with fracture fractal properties of aperture, spacing, and length distribution [14-16]. Hydraulic heterogeneity of fractured rock has been addressed by means of upscaling analysis of classical fracture networks or enhanced stochastic continuum approaches [17].

Conventional DFN modeling approaches have been widely applied to analyze groundwater flow and solute transport through highly heterogeneous fractured rock, as mentioned above $[2,11,12,18,19]$. In these previous studies, DFN parameters (size, orientation, intensity) were determined as statistical distributions obtained mainly from local data such as BHTV (borehole televiewer), geophysical logging, and fracture traces in tunnels/outcrops. When these locally determined DFN parameters are applied to a large-scale model $(>1 \mathrm{~km})$, heterogeneity of the fractured rock cannot be represented properly because the regional fracture heterogeneity cannot be controlled by using only locally determined parameters. Furthermore, fracture hydraulic properties (e.g., transmissivity, hydraulic conductivity) were assigned without taking into account fracture size and connectivity with other fractures. For more reliable site-scale or full-field DFN modeling, incorporation of the following two subjects is required: (i) representation of regional fracture heterogeneity; and (ii) connectivity of conductive fractures.

To understand the nuclide migration path at and around the Gyeongju site, groundwater flow along fractures should be revealed. In the study area, heterogeneous fracture distribution including the density and orientation of the fractures was formed through long periods of various geological activities. This study aims to generate the distribution of hydraulic parameters in the immediate and surrounding fractured bedrock at the Gyeongju site which has experienced geological activities over long periods, especially at the end of Cretaceous. For this study, the DFN approach is undertaken considering detailed analysis of heterogeneous fracture distribution, density, and orientation in the bedrock (Figure 1). To represent the regional fracture heterogeneity, multiple linear regression was applied to find the relationship between local data (borehole fracture intensity) and regional data (faults, electrical resistivity). To take into account the connectivity of conductive fractures, fracture hydraulic parameters were estimated and calibrated using interference test results by simulating transient pressure changes throughout the connected discrete fractures. Upscaling of the DFN into the equivalent porous medium (e.g., FEFLOW) was performed. 


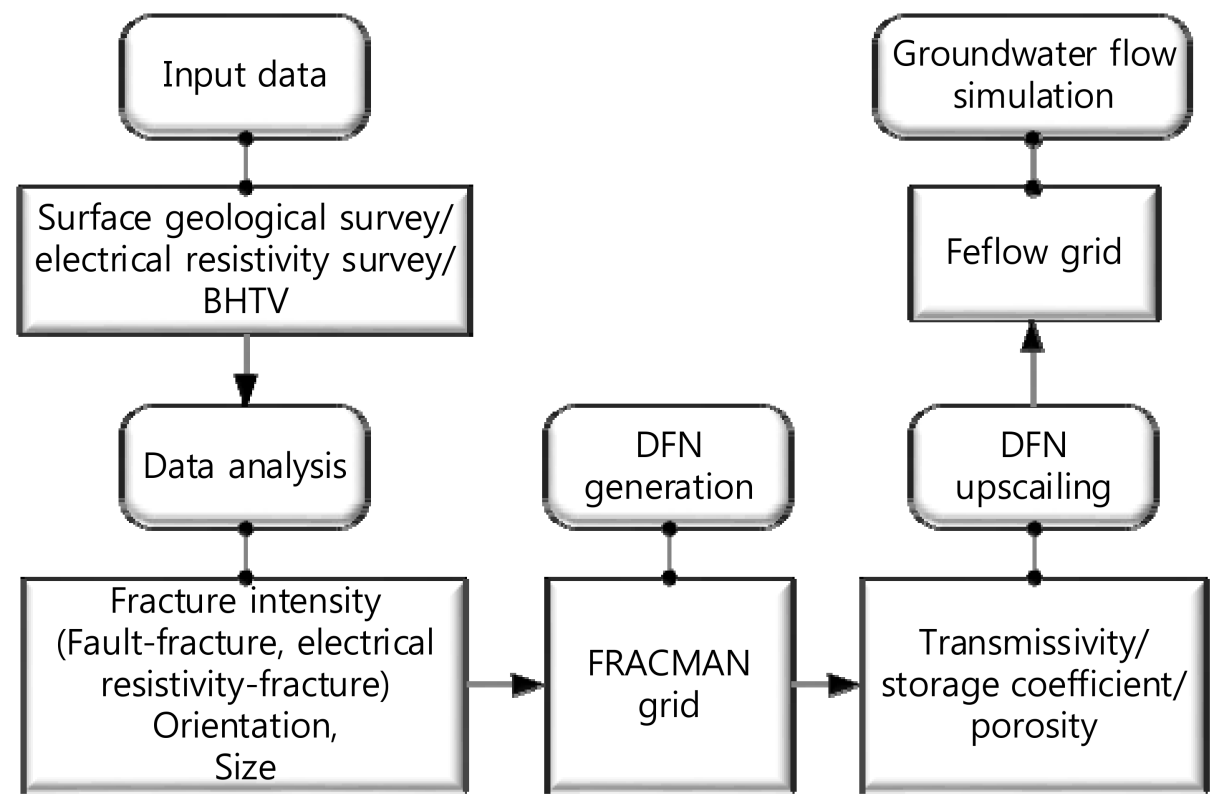

Figure 1. Workflow to build hydraulic properties of fractured rocks incorporating discrete fracture network (DFN) generation and upscaling.

\section{Geological Setting}

The topography of the study area shows an overall decreasing altitude from the west to the east (Figure 2). As the valleys and ridges extend eastward, small streams flow from the highlands in the west into the East Sea. In the vicinity of the estuaries, coastal deposits and small-scale alluvial deposits form. In the study area, the runoff of the small, short stream channels only flow during the wet season, and cease during the dry season.

Geologically, the study site and surrounding area belong to the Gyeongsang supergroup, and consists of Cretaceous sedimentary rocks (shale and sandstone), Tertiary diorite, granodiorite, biotite granite, feldspar porphyry, rhyolite, and basaltic andesite and porphyritic dacitic andesite formed by tertiary volcanic activity (Figure 2). The first stage cavern-disposal facility is located in an area of granite, while the second stage surficial disposal facility is predominately located in an area of sedimentary rock. Substantial fractures and faults occur in both the granite and sedimentary rock areas.

At the Gyeongju site, groundwater mainly moves through the granite and sedimentary rock factures and flows from mountainous areas in the west to the East Sea in the east (Figure 3). Figure 3 was plotted using groundwater heads (a.m.s.l., m) measured in April 2008, prior to construction of the radioactive waste repository. Additionally, the highlands and streams bind the groundwater systems as the eroded hills are geomorphologically bound by the rivers. 


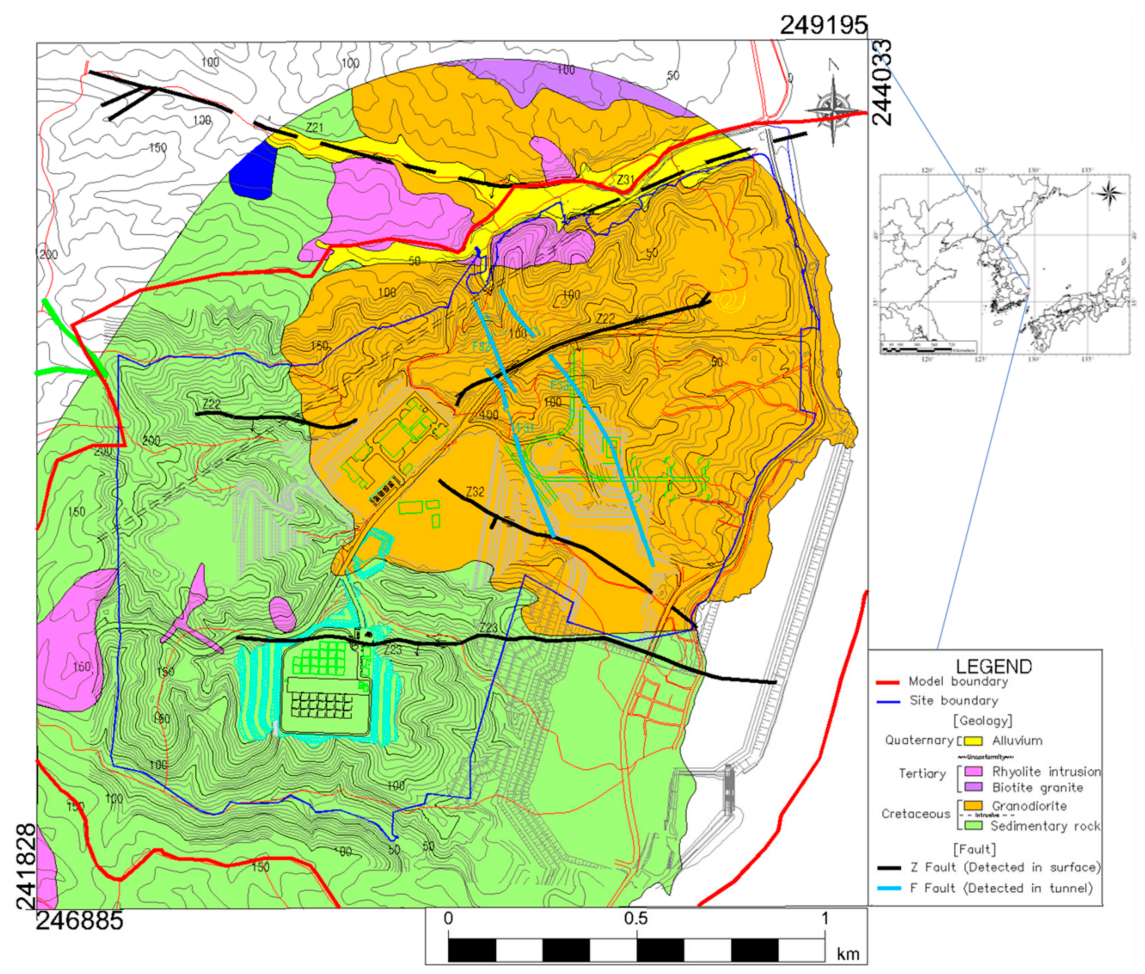

Figure 2. Geology of the study area.

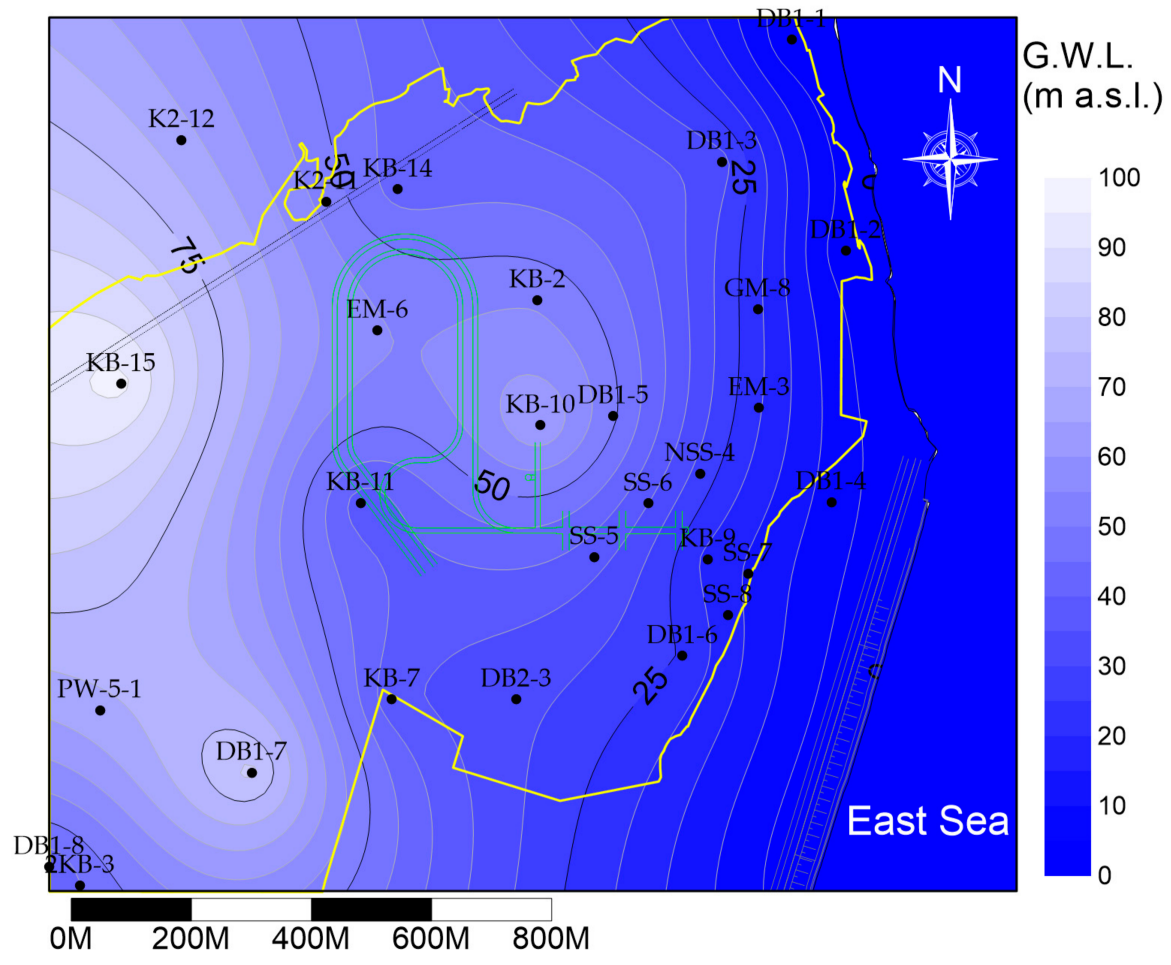

Figure 3. Groundwater head contours (a.m.s.l., m) in the study area. 


\section{Methods}

\subsection{Fault Distribution}

Fractures in the study area were classified as either deterministic faults observed on the land surface or as background fractures identified through underground investigation. A total of 7 major faults and 6 minor faults ranged in length $0.172-1.4 \mathrm{~km}$ and in width $0.2-7 \mathrm{~m}$ (Figure 2). Using the minimum fault length as a cut-off value, background fractures were defined as those having a length of $172 \mathrm{~m}$ or less. A stochastic realization of the background fracture was generated for the three-dimensional DFN model using the software package FracMan ${ }^{\circledR}$ (version. 7.6) considering the location, direction, length, and width of the faults and borehole fractures (Table 1).

Table 1. Properties of the deterministic faults in the study area.

\begin{tabular}{cccccccc}
\hline Fault No. & Z21 & Z22 & Z23 & Z31 & Z32 & F31 & F33 \\
\hline Strike/dip & $\begin{array}{c}\mathrm{N} 75^{\circ} \mathrm{W} / \\
50^{\circ} \mathrm{SW}\end{array}$ & $\begin{array}{c}\mathrm{N} 60^{\circ} \mathrm{E} / \\
55^{\circ} \mathrm{SE}\end{array}$ & $\begin{array}{c}\mathrm{N} 80^{\circ} \mathrm{E} / \\
64^{\circ} \mathrm{SE}\end{array}$ & $\begin{array}{c}\mathrm{N} 60^{\circ} \mathrm{E} / \\
72^{\circ} \mathrm{SE}\end{array}$ & $\begin{array}{c}\mathrm{N} 63^{\circ} \mathrm{W} / \\
65^{\circ} \mathrm{SW}\end{array}$ & $\begin{array}{c}\mathrm{N} 25^{\circ} \mathrm{W} / \\
61^{\circ} \mathrm{NE}\end{array}$ & $\begin{array}{c}\mathrm{N} 25^{\circ} \mathrm{W} / \\
60^{\circ} \mathrm{NE}\end{array}$ \\
\hline Damage zone $(\mathrm{m})$ & 7.9 & 4.8 & 5.6 & 8.3 & 2.2 & $0.2-10.0$ (ave. 5.0$)$ & $0.6-8.0($ ave. 5.0$)$ \\
\hline Length $(\mathrm{km})$ & 1.1 & 1.4 & 1.26 & 0.73 & 0.8 & 0.65 & 0.75 \\
\hline
\end{tabular}

\subsection{Geophysical Survey and Borehole Logging}

An electrical resistivity survey was performed on a total of 49 survey lines, and resulted in measured electrical resistivity values ranging from $1 \Omega \mathrm{m}$ to $10,000 \Omega \mathrm{m}$ (Figure 4 ). The result was utilized for analyzing the relationship between fractures and electrical resistivity.

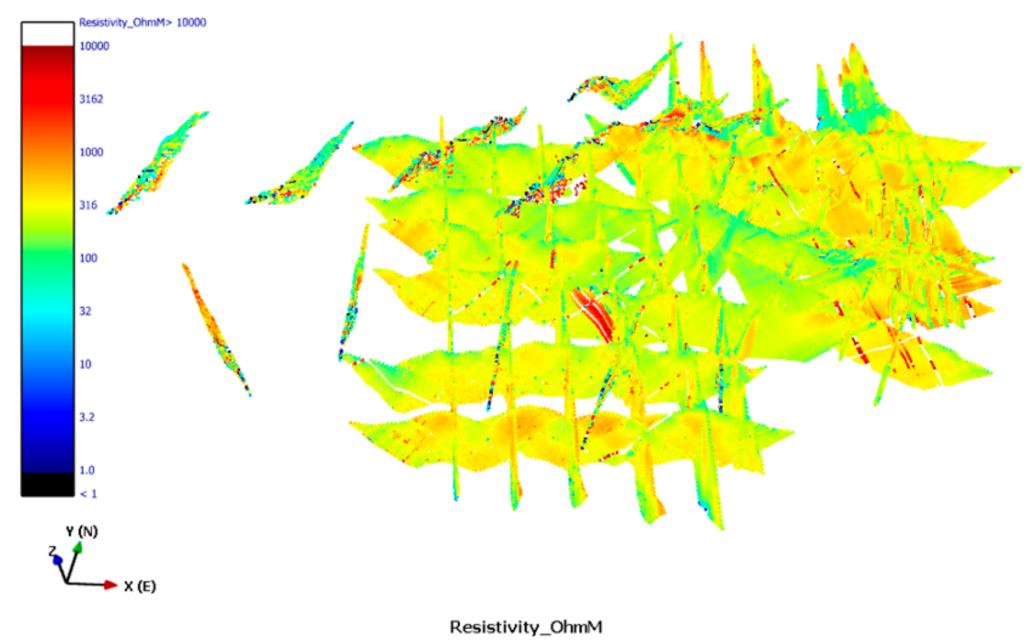

Figure 4. Result of electrical resistivity survey in the study area.

BHTV (borehole televiewer) logging that was conducted on 60 boreholes ranging from 54.0 to $302.4 \mathrm{~m}$ in depth provided borehole log images of fractures with dip directions and angles along the borehole (Figure 5). The BHTV logs show dip angles of mostly more than $60^{\circ}$ and major dip directions of NNW-SSE with variability. Figure 6 shows equal-area stereonets projected to lower hemispheres using the 60 BHTV data, indicating diversely oriented fractures that reflect the complex geological structures. The number of the 60 BHTV log fractures that were evenly located in the range of $2 \mathrm{~km}$ scale horizontally were enough to represent background fractures in the study area. The orientations of the fractures in the study area were interpolated using a bootstrap method that estimated the orientations from the BHTV data honoring its inverse distance squared to the data points. From the BHTV, 1-dimensional fracture density was determined as the number of fractures along the borehole depth. 

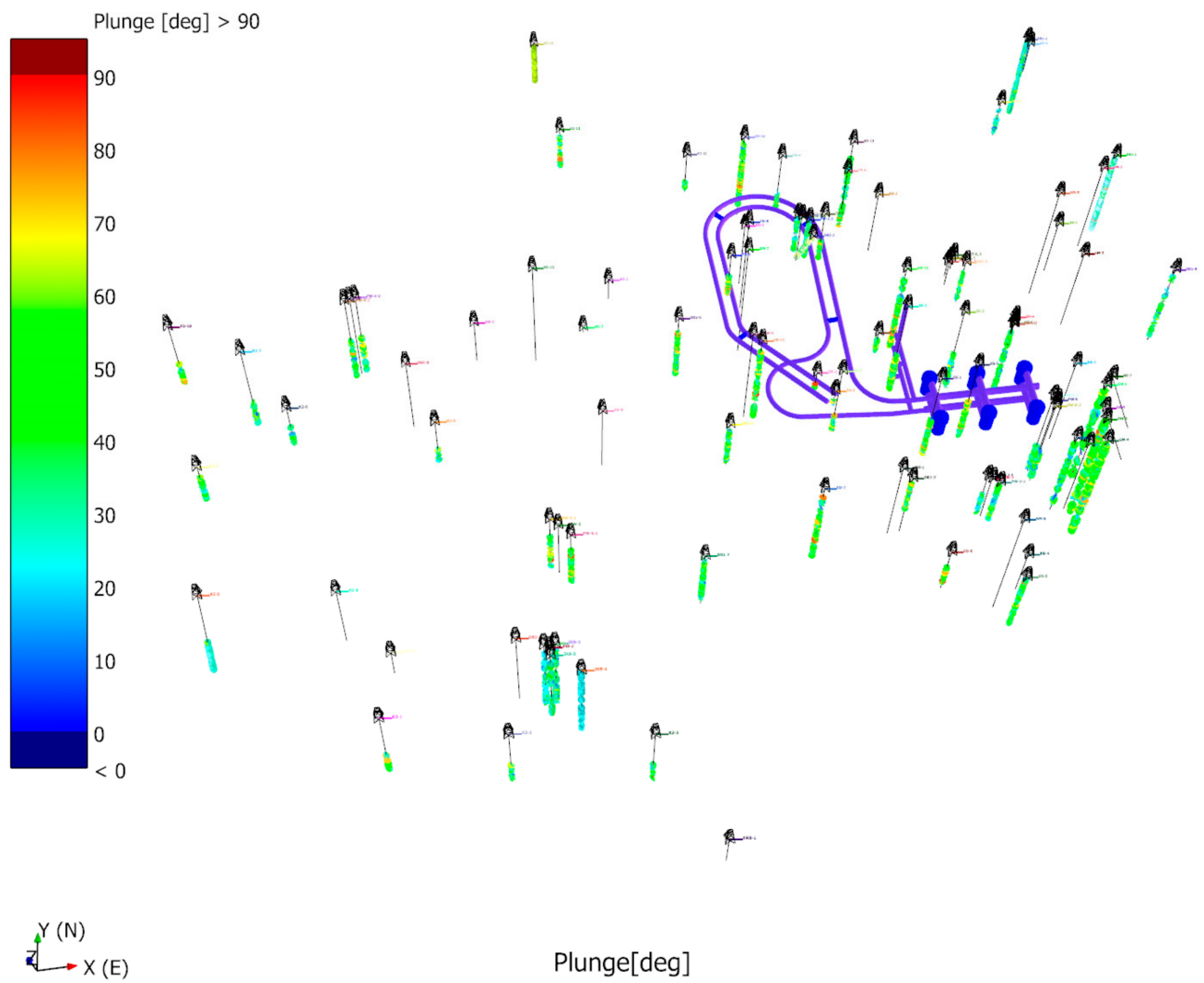

Figure 5. Result of the BHTV logs in the boreholes.

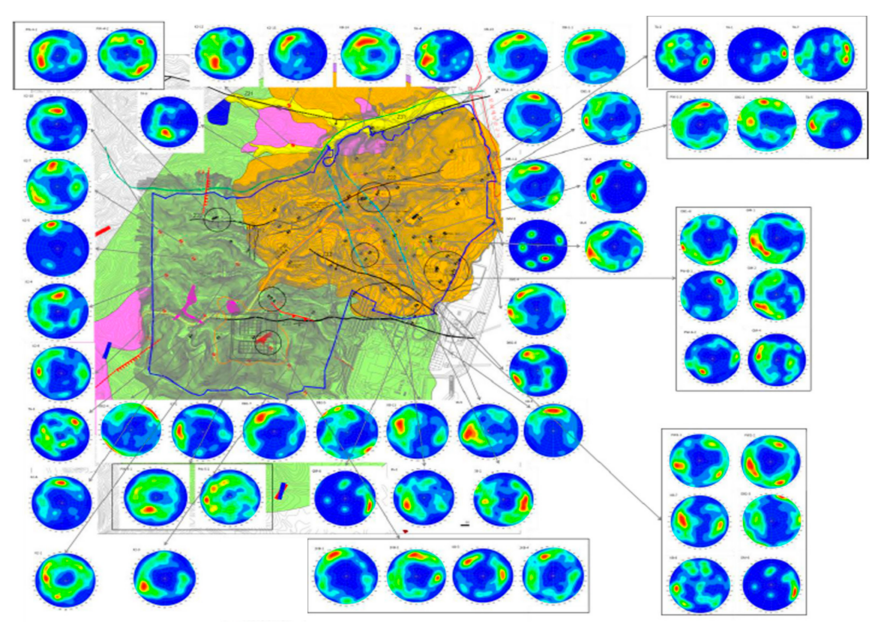

Figure 6. Stereonet contour plots of open/filled fracture orientation and dip obtained from the BHTV data.

\subsection{DFN Upscaling to the FEFLOW Grid}

A geologically realistic DFN model enables the most accurate estimation of flow predictions. Nevertheless, these DFN models are often prohibitively expensive from the gridding and flow simulation standpoints. To reduce the computational cost of a full DFN while preserving the complex geological information in the DFN, the DFN model can be upscaled for use in conventional equivalent porous media flow simulators including the FEFLOW (Finite Element subsurface FLOW system) program. 
DFN upscaling utilizes a simplification of Darcy's Law for laminar flow through a porous medium by projecting the fracture hydraulic conductivity on to the plane of the fracture, and scaling it by the ratio between the fracture volume and the volume of the simulation grid cell [20]. The result is a $3 \times 3$ matrix describing the directional hydraulic conductivity tensor in each fracture, and these matrices can be summed to calculate a net hydraulic conductivity tensor for the grid cell. The principal hydraulic conductivity for each grid cell can be obtained by the eigenvector analysis of the hydraulic conductivity tensor. As a result of DFN upscaling, the resulting FEFLOW grid in the model domain (Figure 7) retains the heterogeneous and anisotropic hydraulic conductivity parameters characterized by the DFN.
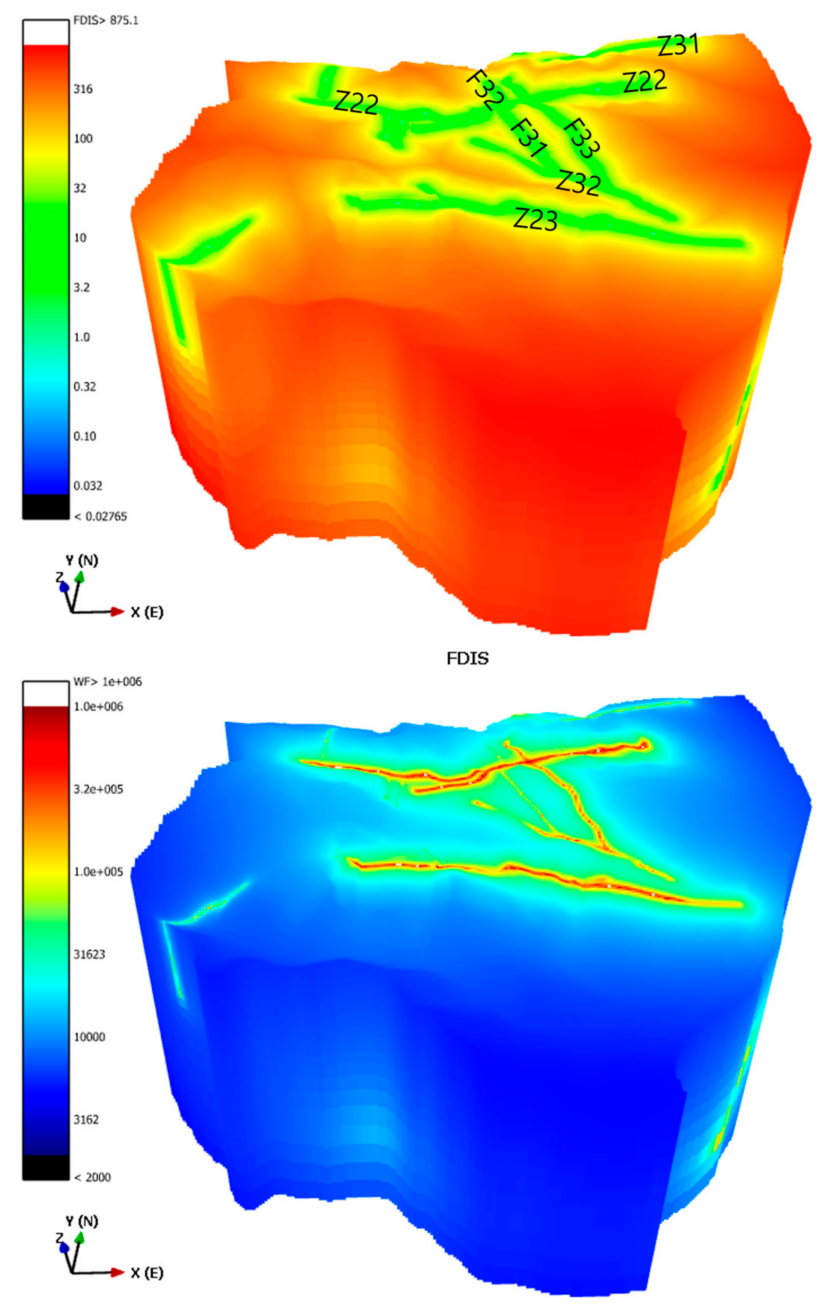

WF

Figure 7. FDIS (minimum distance to fault) and WF (normalized inverse distance from the faults weighted by nearest fault size).

\section{Results}

\subsection{Relationship between Fault and Fracture Intensity}

Fracture intensity is defined by "Pxy" notation in this study [20]. The two subscripts $x$ and $y$ refer to the dimensions of the sampling space and of the sample measure (respectively), such that that ' 3 ' is volume, ' 2 ' is area, ' 1 ' is length, and ' 0 ' is count. For example, $P_{10}[1 / \mathrm{m}]$ is the number of fracture per unit length, $\mathrm{P}_{32}\left[\mathrm{~m}^{2} / \mathrm{m}^{3}\right]$ is the total fracture area per unit volume, and $\mathrm{P}_{33}\left[\mathrm{~m}^{3} / \mathrm{m}^{3}\right]$ is the total 
fracture volume per unit volume. $\mathrm{P}_{32}$ is determined as $\mathrm{P}_{10}$ multiplied by conversion factor [21]. $\mathrm{P}_{33}$ is computed as $\mathrm{P}_{32}$ multiplied by aperture size.

The minimum distance from fault (FDIS) and fracture density along depth $\left(\mathrm{P}_{10}\right)$ as well as the normalized inverse distance from faults weighted by nearest fault size (WF) and $\mathrm{P}_{10}$ were examined to relate fault and fracture intensity (Figure 7). The Pearson correlation coefficient of FDIS vs. $\mathrm{P}_{10}$ was -0.141 , with a significance level of 0.128 . On the other hand, the Pearson correlation coefficient of WF vs. $P_{10}$ was 0.261 , with a significance level of 0.00435 . Therefore, the relation of WF vs. $P_{10}$ was more significant, indicating that the greater the fault size, the higher the fracture intensity.

\subsection{Relationship between Electrical Resistivity and Fracture}

The electrical resistivity survey data were correlated with the fracture density data of the boreholes located along the resistivity survey lines. When considering a 10-m survey line, the correlation analysis was performed using the maximum, minimum, and mean resistivity values within $10 \mathrm{~m}$ of the boreholes' intersections, and resulted in correlation coefficients of $-0.049,-0.123$, and -0.056 , and significance levels of $0.596,0.550$, and 0.185 , respectively. The relatively low correlation coefficients of the maximum and mean values were due to a few high-resistivity values.

\subsection{Multiple Linear Regression Analysis}

Multiple linear regression is a statistical analysis method used to predict a dependent variable (or observed data) from two or more independent variables. In order to reflect the heterogeneity of the study area, multiple linear regression analyses of $\mathrm{P}_{10}$ were performed using two independent variables: the inverse distance from the faults weighted by nearest fault size, and the minimum electrical resistivity value. The resulting regression model for fracture intensity $\left(\mathrm{P}_{10}\right)$ was obtained as (Figure 8):

$$
\mathrm{P}_{10}=2.365+3.265 \times 10^{-5} \mathrm{WF}-2.357 \times 10^{-5} \mathrm{R}_{\text {mean }}
$$

where WF is the normalized inverse distance from the faults weighted by nearest fault size, and $R_{\text {mean }}$ is the normalized mean electrical resistivity value. The significance level of the regression model, $\mathrm{WF}$, and $\mathrm{R}_{\text {mean }}$ were $0.005,0.001$, and 0.117 , respectively. The VIF (variance inflation factor) is 1.0992 (i.e., no collinearity problem). The effect of the WF on fractures was 1.38 times larger than the $R_{\text {mean }}$. The obtained regression model in Equation (1) shows that fracture intensity is higher with increasing WF and decreasing $R_{\text {mean, }}$ which can be interpreted to mean that fracture intensity is increased at the locations closer to the large faults and having smaller mean electrical resistivity. This result corresponds well with having a higher degree of fracturing in the vicinity of faults and lower electrical resistivity in fracture zones containing groundwater.

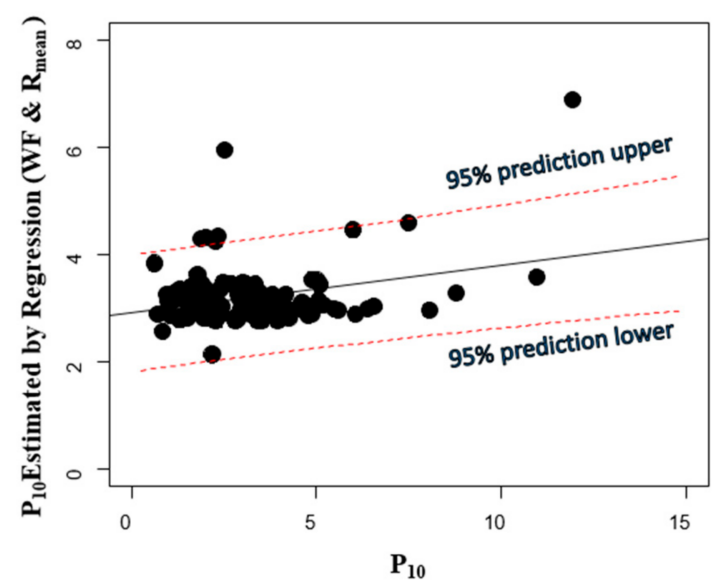

Figure 8. Estimated $\mathrm{P}_{10}$ by multiple regression analysis. 


\subsection{Upscaling of Hydraulic Parameters}

Hydraulic parameters of discrete fractures should be converted to equivalent hydraulic parameters on grids by upscaling. In this study, the transmissivity $\left(\mathrm{T}\left[\mathrm{m}^{2} / \mathrm{s}\right]\right)$ and storage coefficient (S [-]) of fractures were estimated using the transient flow simulations performed by finite element modeling in FracMan ${ }^{\circledR}$, a method called dynamic calibration. The dynamic calibration determined the hydraulic parameters of fractures having a fracture radius ranging from $14 \mathrm{~m}$ to $172 \mathrm{~m}$ by matching numerically simulated flow through the DFN model with the actual pressure transient data obtained in the field. Upscaling determined the hydraulic parameters of the fractures ranging from $1.5 \mathrm{~m}$ to $172 \mathrm{~m}$ as explained below.

In the current DFN model, the volumetric fracture intensity of $P_{32}$ is $3.0\left[\mathrm{~m}^{2} / \mathrm{m}^{3}\right]$ obtained from $60 \mathrm{BHTV}$ data, and the minimum fracture radius is $1.5 \mathrm{~m}(\mathrm{r} \geq 1.5 \mathrm{~m})$ which was estimated based on a fracture size analysis using measured fracture traces in underground tunnel silos. Transmissivity (T) and storage coefficients (S) were first determined by the dynamic calibration of a fracture radius of $14 \mathrm{~m}$ or more using interference test results by matching transient pressure changes throughout the constructed DFN model. Interference tests are pumping tests that are performed when monitoring heads in observations wells. They are particularly useful for determining connectivity in fracture networks. Then, $\mathrm{T}$ and $\mathrm{S}$ calculated using a fracture radius $(\mathrm{r})$ of $14 \mathrm{~m}$ or more (i.e., $r \geq 14 \mathrm{~m}$ ) are calibrated by compensating excluded fractures with a fracture radius between $1.5 \mathrm{~m}$ and $14 \mathrm{~m}$. Thus, hydraulic parameters for each fracture are obtained for all fractures in the current DFN model $(\mathrm{r} \geq 1.5 \mathrm{~m}$ ) (Table 2). The calibrated hydraulic parameters were applied to the DFN upscaling. The mean T values of the granite and sedimentary rock areas were $1.05 \times 10^{-7}\left[\mathrm{~m}^{2} / \mathrm{s}\right]$ and $2.45 \times 10^{-7}\left[\mathrm{~m}^{2} / \mathrm{s}\right]$, respectively. The distributions of fracture T values represented in the DFN are shown in Figure 9. The hydraulic conductivity tensors $\left(\mathrm{K}_{\mathrm{xx}}, \mathrm{K}_{\mathrm{yy}}\right.$, and $\left.\mathrm{K}_{\mathrm{zz}}\right)$ were calculated as $T$ values divided by the aperture size depending on axes. The upscaled mean $(\mu)$ and standard deviation $(\sigma)$ of $\mathrm{K}_{\mathrm{xx}}, \mathrm{K}_{\mathrm{yy}}$, and $\mathrm{K}_{\mathrm{zz}}$ were obtained for the FEFLOW grid as $\left(\mu=8.25 \times 10^{-8} \mathrm{~m} / \mathrm{s}\right.$ and $\left.\sigma=6.97 \times 10^{-8} \mathrm{~m} / \mathrm{s}\right),\left(8.42 \times 10^{-8} \mathrm{~m} / \mathrm{s}, 7.04 \times 10^{-8} \mathrm{~m} / \mathrm{s}\right)$, and $\left(8.11 \times 10^{-8} \mathrm{~m} / \mathrm{s}, 6.67 \times 10^{-8} \mathrm{~m} / \mathrm{s}\right)$, respectively (Table 3$)$.

Table 2. Hydraulic parameters for DFN upscaling in granite and sedimentary rock regions.

\begin{tabular}{cc}
\hline Region & Relationship of Hydraulic Parameter vs. Fracture Radius (r) \\
\hline Granite & Aperture $[\mathrm{m}]=0.011 \log _{10}(\mathrm{r})$ \\
& $\begin{array}{c}\text { Storativity }[-]=4.65 \times 10^{-6} \log _{10}(\mathrm{r}) \\
\text { Transmissivity }\left[\mathrm{m}^{2} / \mathrm{s}\right]=1.5 \times 10^{-7}\left[\log _{10}(\mathrm{r})\right]^{2}\end{array}$ \\
\hline Sedimentary rock & Aperture $[\mathrm{m}]=0.0196 \log _{10}(\mathrm{r})$ \\
& Storativity $[-]=7.81 \times 10^{-6} \log _{10}(\mathrm{r})$ \\
& Transmissivity $\left[\mathrm{m}^{2} / \mathrm{s}\right]=3.5 \times 10^{-7}\left[\log _{10}(\mathrm{r})\right]^{2}$ \\
\hline
\end{tabular}

A total of 3,834,554 grid cells were generated by FEFLOW for the DFN upscaling, as shown in Figure 10. The porosity of the fractures and the hydraulic conductivity tensor were calculated for each grid cell that was generated by the upscaling process. Spatial upscaled hydraulic conductivity tensors and bar graphs are displayed in Figures 11-13. Fracture porosity is the total volume of the fractures divided by the volume of each grid cell. The representative fracture porosity values corrected by the upscaling had a mean value of 0.014 with a standard deviation of 0.001 . Figure 14 shows the spatial distribution of the corrected facture porosities with a bar graph. Hence, it was identified that the upscaled FEFLOW grid incorporated the heterogeneity and anisotropy of the fractured bedrock in the Gyeongju site, based on the distribution of the hydraulic conductivity tensors and porosity. 


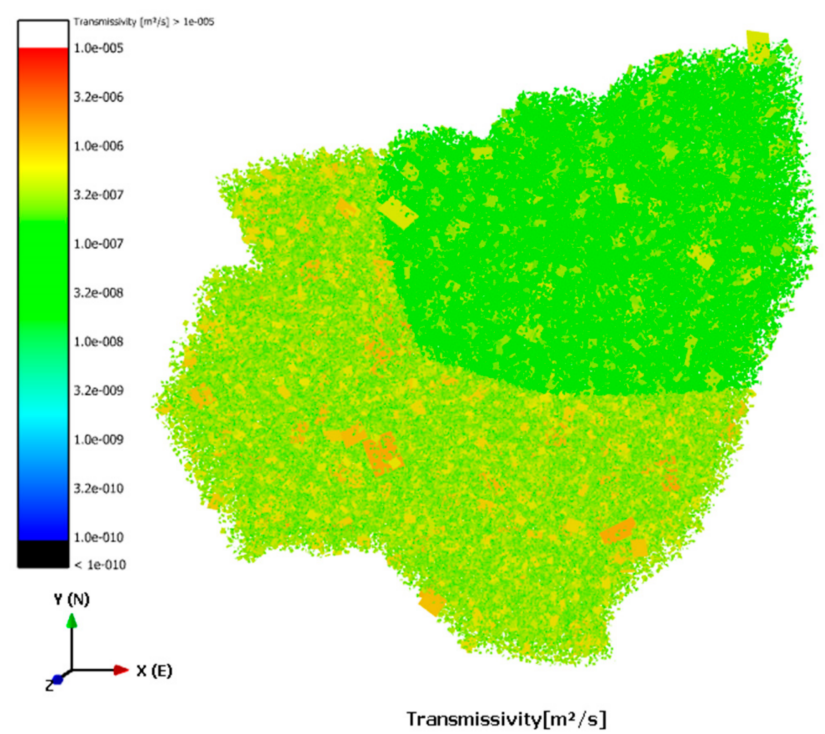

Granite Region

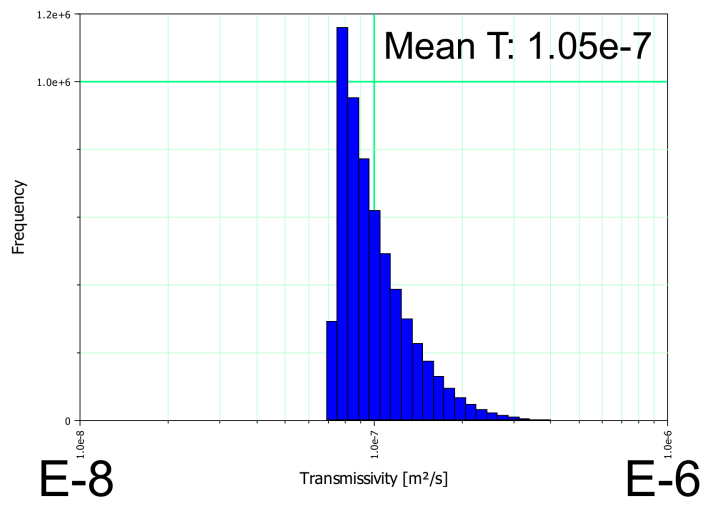

Sedimentary Region

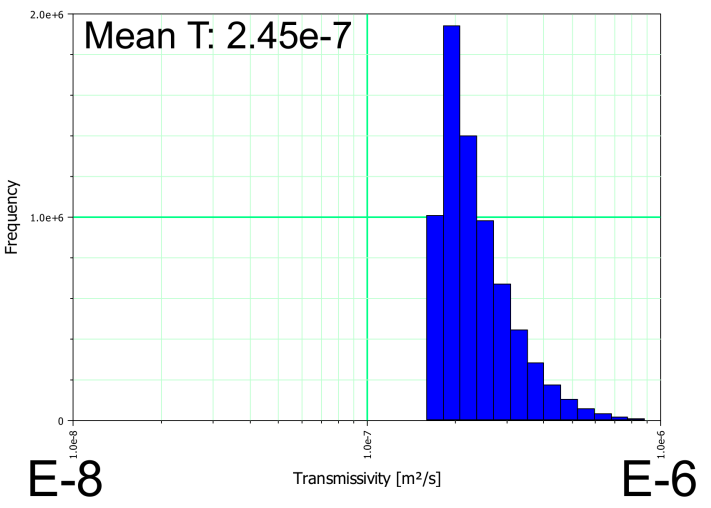

Figure 9. DFN transmissivity distribution for granite and sedimentary rock regions.

Table 3. Upscaled hydraulic conductivity.

\begin{tabular}{ccc}
\hline Hydraulic Conductivity Tensor [m/s] & Mean $[\mathrm{m} / \mathrm{s}]$ & Standard Deviation $[\mathrm{m} / \mathbf{s}]$ \\
\hline $\mathrm{K}_{\mathrm{xx}}$ & $8.25 \times 10^{-8}$ & $6.97 \times 10^{-8}$ \\
$\mathrm{~K}_{\mathrm{yy}}$ & $8.42 \times 10^{-8}$ & $7.04 \times 10^{-8}$ \\
$\mathrm{~K}_{\mathrm{zz}}$ & $8.11 \times 10^{-8}$ & $6.67 \times 10^{-8}$ \\
\hline
\end{tabular}




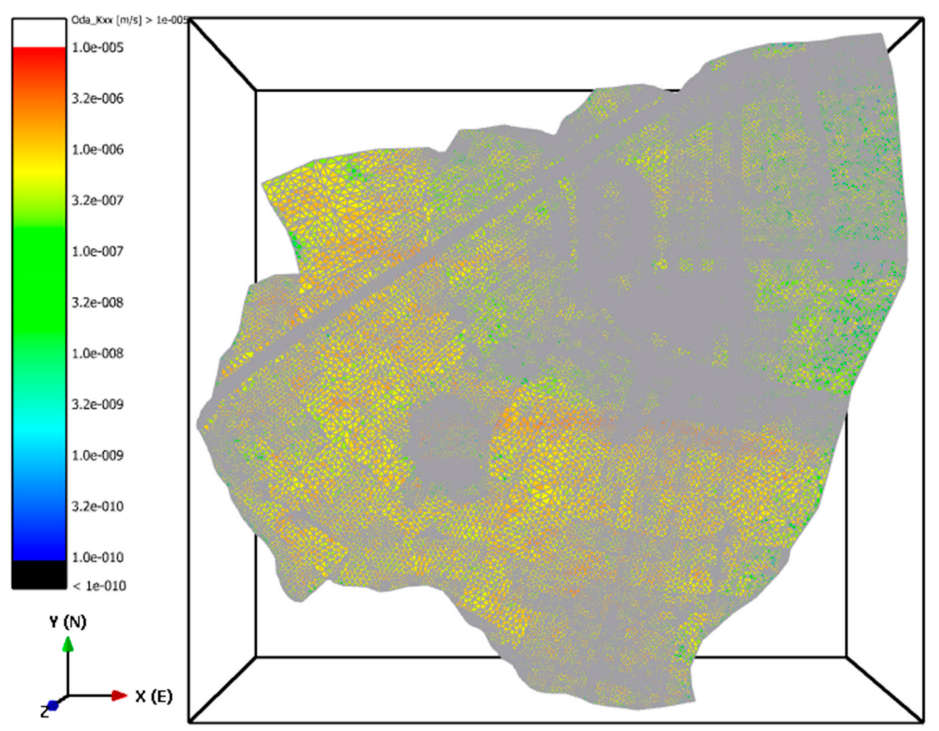

Figure 10. FEFLOW grid for upscaling.

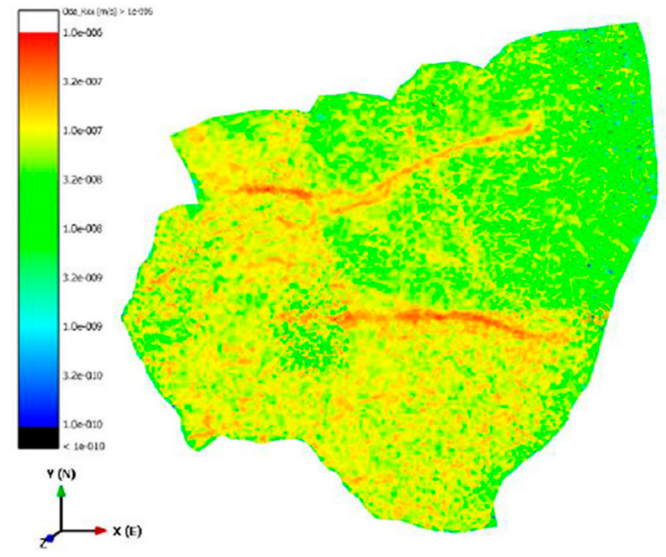

Ode_K $\times \times[\mathrm{m} / \mathrm{s}]$

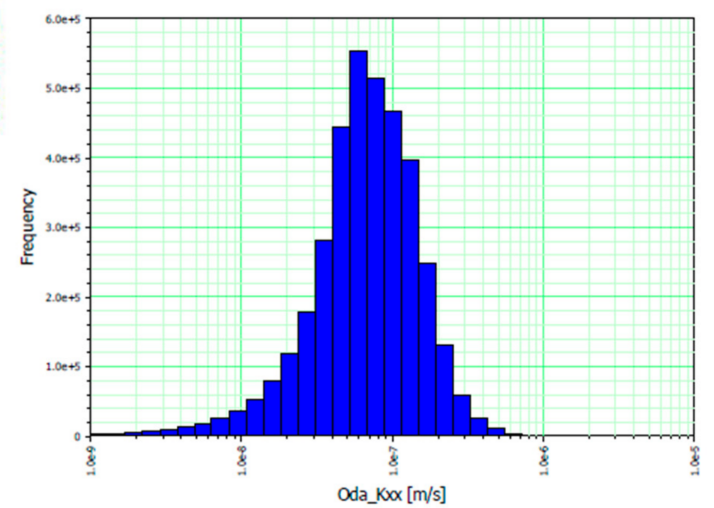

Figure 11. Upscaled hydraulic conductivity tensor in $x$-direction, $K_{x x}[\mathrm{~m} / \mathrm{s}]$.
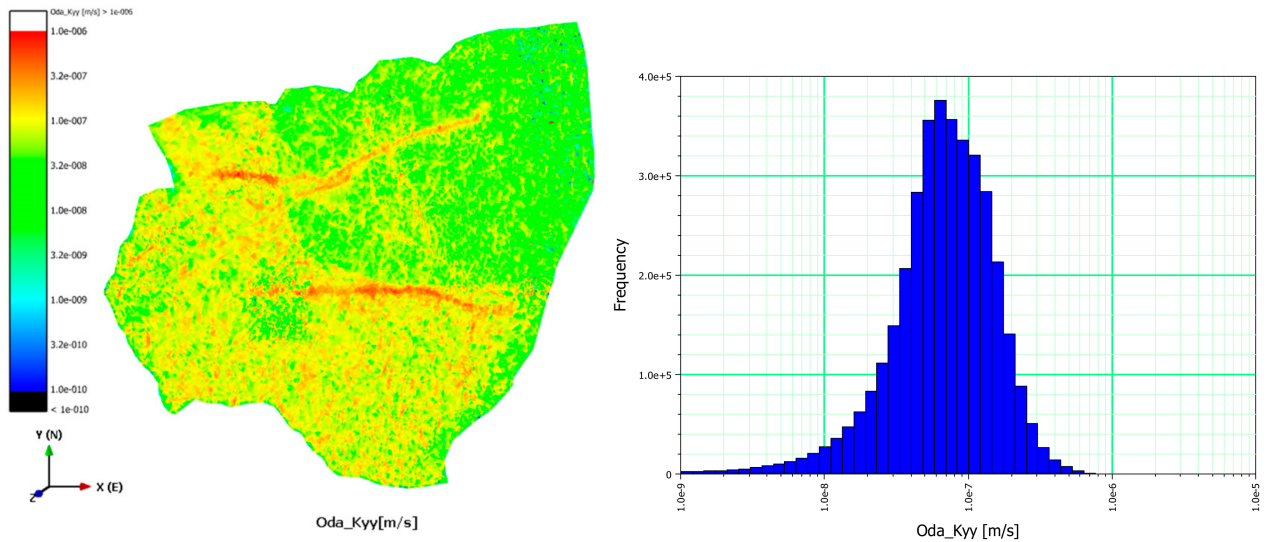

Figure 12. Upscaled hydraulic conductivity tensor in $y$-direction, $K_{y y}[\mathrm{~m} / \mathrm{s}]$. 


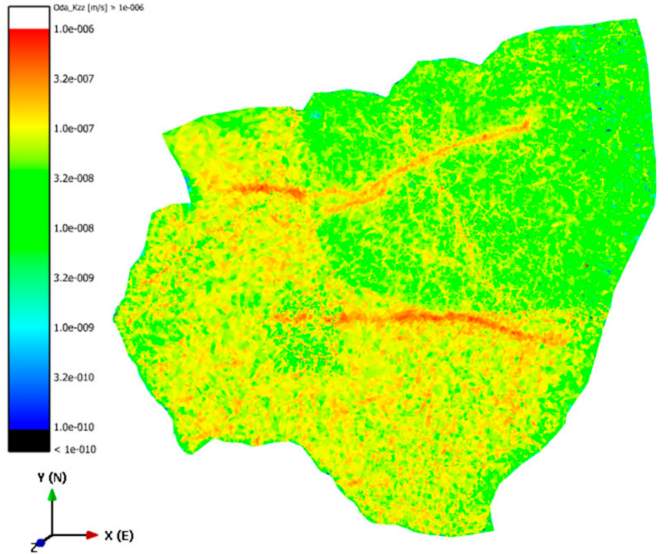

Oda_Kzz $[\mathrm{m} / \mathrm{s}]$

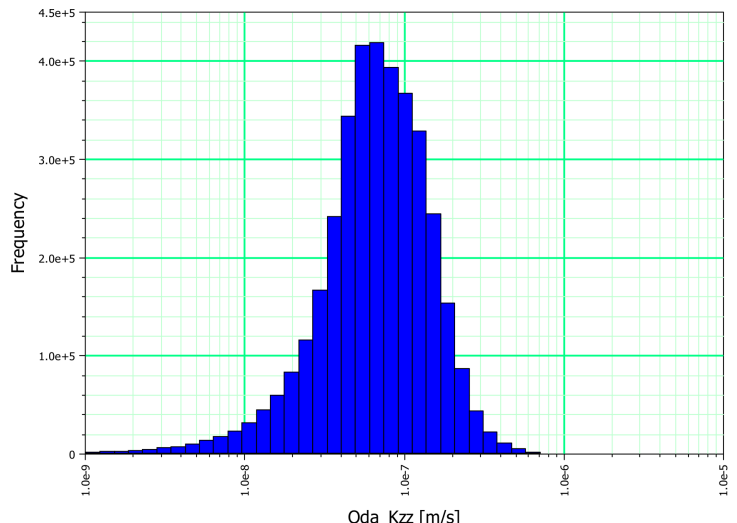

Oda_Kzz $[\mathrm{m} / \mathrm{s}]$

Figure 13. Upscaled hydraulic conductivity tensor in z-direction, $\mathrm{K}_{\mathrm{zz}}[\mathrm{m} / \mathrm{s}]$.
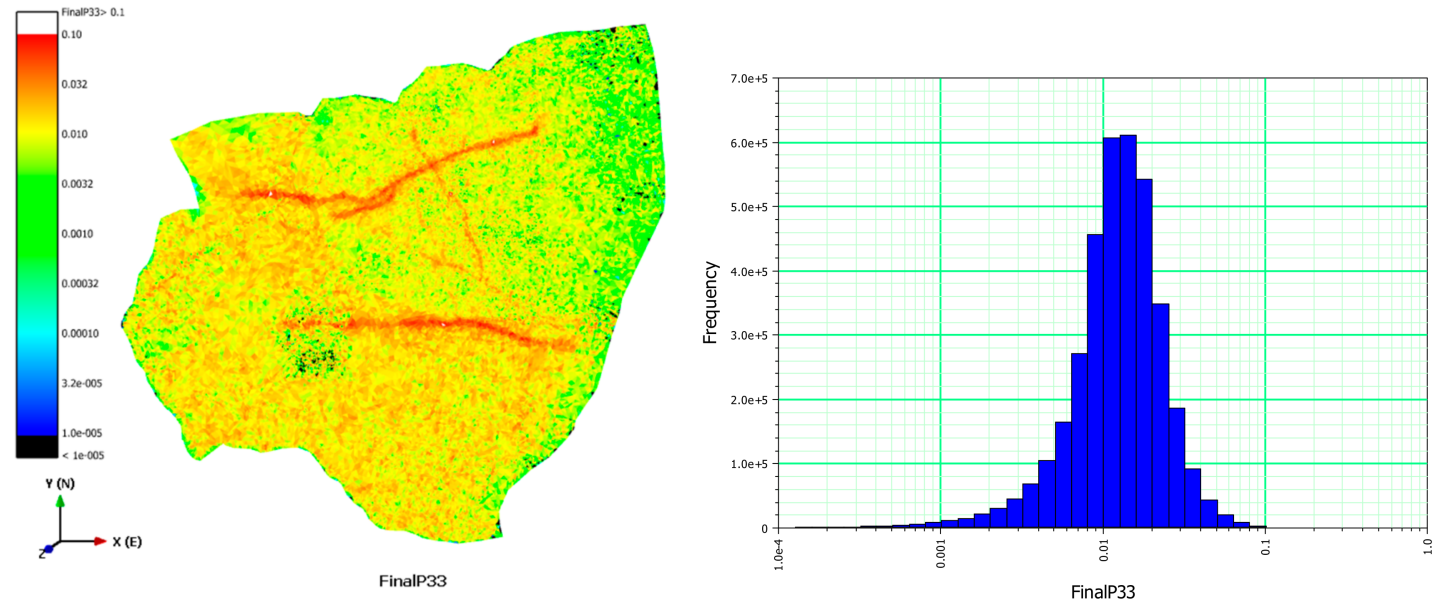

Figure 14. Upscaled fracture porosity distribution.

\section{Conclusions}

A 3-D discrete fracture network (DFN) model was constructed taking into account regional fracture heterogeneity and the connectivity of conductive fractures for the Gyeongju radioactive waste disposal site in Korea. The DFN model incorporated a total of 13 deterministic faults with lengths between $172 \mathrm{~m}$ and $1.4 \mathrm{~km}$ as well as an average volumetric background fracture intensity $\left(\mathrm{P}_{32}=3.0\left[\mathrm{~m}^{2} / \mathrm{m}^{3}\right]\right)$ with fracture radius between $1.5-172 \mathrm{~m}$. This study showed that fracture intensity was increased at the locations closer to the large faults and of lower electrical resistivity in the study area. The regional heterogeneity of fracture intensity was incorporated using a multiple regression analysis such that $1 \mathrm{D}$ fracture intensity was estimated as $\mathrm{P}_{10}=2.365+3.265 \times 10^{-5} \mathrm{WF}-2.357 \times 10^{-5} \mathrm{R}_{\text {mean }}$, indicating that fracture intensity varied with respect to the normalized inverse distance from the faults weighted by nearest fault size (WF) in terms of the geological aspect, and the normalized mean electrical resistivity value $\left(R_{\text {mean }}\right)$ in terms of the geophysical aspect.

The hydraulic parameters (transmissivity and storage coefficient) of discrete fractures were determined by transient flow simulation through the connected conductive fractures. Average fracture transmissivity was obtained as $1.5 \times 10^{-7}\left[\mathrm{~m}^{2} / \mathrm{s}\right]$ for the granite area and $2.45 \times 10^{-7}\left[\mathrm{~m}^{2} / \mathrm{s}\right]$ for the sedimentary rock area. The upscaled mean $(\mu)$ and standard deviation $(\sigma)$ of hydraulic conductivity tensors for a FEFLOW grid were determined as $\left(\mu=8.25 \times 10^{-8} \mathrm{~m} / \mathrm{s}\right.$ and $\left.\sigma=6.97 \times 10^{-8} \mathrm{~m} / \mathrm{s}\right),\left(8.42 \times 10^{-8} \mathrm{~m} / \mathrm{s}, 7.04 \times 10^{-8} \mathrm{~m} / \mathrm{s}\right)$, and $\left(8.11 \times 10^{-8} \mathrm{~m} / \mathrm{s}, 6.67 \times 10^{-8} \mathrm{~m} / \mathrm{s}\right)$ for $\mathrm{K}_{\mathrm{xx}}, \mathrm{K}_{\mathrm{yy}}$, and $\mathrm{K}_{\mathrm{zz}}$, respectively. 
The upscaled FEFLOW grid incorporated the heterogeneity and anisotropy of the fractured bedrock in the Gyeongju site reasonably well, based on the distribution of the hydraulic conductivity tensors and porosity. Therefore, the estimated hydraulic parameter using the current DFN model will be utilized for the groundwater flow and radionuclide transport analyses in order to assess the performance and safety of radioactive waste disposal sites in Korea.

Acknowledgments: This work was funded by the Korea Institute of Energy Technology Evaluation and Planning (KETEP), the Ministry of Trade, Industry \& Energy (MOTIE) of the Republic of Korea (grant No. 20141720100570), and the Korea Meteorological Administration Research and Development program under grant KMIPA 2017-9050.

Author Contributions: The idea of this article was developed by J.-Y. Cheong. The text was mainly written by J.-Y. Cheong, S.-Y. Hamm, and D.-H. Lim with partial contribution of S.-G. Kim.

Conflicts of Interest: The authors declare no conflict of interest.

\section{References}

1. Lim, D.-H. Mass Transport Analysis in the Near Field of Geologic Repository. Ph.D. Thesis, University of California, Berkeley, CA, USA, 2002.

2. Fox, A.; Forchhammer, K.; Pettersson, A.; La Pointe, P.; Lim, D.-H. Geological Discrete Fracture Network Model for the Olkiluoto Site, Eurajoki, Finland. Version 2.0; POSIVA 2012-27; POSIVA OY: Eurajoki, Finland, 2012.

3. Lim, D.-H. Probabilistic transport path analysis through three-dimensional discrete fracture network for underground radioactive waste disposal facilities. In Proceedings of the 13th International Conference on Probabilistic Safety Assessment and Management, Seoul, Korea, 2-7 October 2016.

4. Will, R.; Archer, R.; Dershowitz, W. Integration of seismic anisotropy and Reservoir-Performance data for characterization of naturally fractured reservoirs using Discrete-Feature-Network models. SPE Reserv. Eval. Eng. 2005, 8, 132-142. [CrossRef]

5. Rogers, S.; Lim, D.-H.; Fejer, P.; Han, G. Static and dynamic data integration for improved characterisation of a fractured gas reservoir. In Proceedings of the 46th US Rock Mechanics/Geomechanics Symposium, American Rock Mechanics Association, Chicago, IL, USA, 24-27 June 2012.

6. McClure, M.W.; Horne, R.N. Discrete fracture modeling of hydraulic simulation in enhanced geothermal systems. In Proceedings of the 35th Workshop on Geothermal Reservoir Engineering, Stanford, CA, USA, 1-3 February 2010; SGP-TR-188.

7. Finnila, A.; Dershowitz, W.; Doe, T.; McLaren, R. Hydro-shearing and hydraulic fracturing for enhanced geothermal systems in archetypical normal, strike-slip and thrust faulting terrains. GRC Trans. 2015, 39, 19.

8. Dershowitz, W. Rock Joint Systems. Ph.D. Thesis, Massachusetts Institute of Technology, Cambridge, MA, USA, 1984.

9. Uchida, M.; Dershowitz, W.; Lee, G.; Shuttle, D. An empirical probabilistic approach for constraining the uncertainty of long-term solute transport predictions in fractured rock using in situ tracer experiments. Hydrogeol. J. 2009, 17, 1093-1110. [CrossRef]

10. Dershowitz, W.; Shuttle, D.; Lee, G.; Rogers, S. Analysis of groundwater inflow control by grouting using the discrete fracture network method. Felsbau 2007, 25, 34-41.

11. Munier, R. Statistical Analysis of Fracture Data, Adapted for Modelling Discrete Fracture Networks-Version 2; SKB R-04-66; Svensk Kärnbränslehantering AB: Östhammar, Sweden, 2004.

12. Hartley, L.; Hoek, J.; Swan, D.; Roberts, D.; Joyce, S.; Follin, S. Development of a Hydrogeological Discrete Fracture Network Model for the Olkiluoto Site Descriptive Model 2008; Working Report 2009-61; POSIVA OY: Eurajoki, Finland, 2009.

13. Hyman, J.D.; Karra, S.; Makedonska, N.; Gable, C.W.; Painter, S.L.; Viswanathan, H.S. DfnWORKS: A discrete fracture network framework for modeling subsurface flow and transport. Comput. Geosci. 2015, 84, 10-19. [CrossRef]

14. Kim, T.H.; Schechter, D. Estimation of facture porosity of naturally fractured reservoirs with no matrix porosity using fractal discrete fracture networks. SPE Res. Eval. Eng. 2009, 12, 232-242.

15. Sun, J.; Schechter, D. Optimization-based unstructured meshing algorithms for simulation of hydraulically and naturally fractured reservoirs with variable distribution of fracture aperture, spacing, length, and strike. SPE Res. Eval. Eng. 2015, 8. [CrossRef] 
16. Zhang, L.; Einstein, H.H.; Dershowitz, W. Stereological relationship between trace length and size distribution of elliptical discontinuities. Geotechnique 2002, 52, 419-433. [CrossRef]

17. Öhman, J.; Niemi, A. Upscaling of fracture hydraulics by means of an oriented correlated stochastic continuum model. Water Resour. Res. 2003, 1277. [CrossRef]

18. Shin, H.J. Hydrogeological Characterization of Fractured Crystalline Rock and It's Application to Discrete Fracture Network Model. Ph.D. Thesis, Yonsei University, Seoul, Korea, 2001.

19. Ji, S.H.; Park, K.W.; Lim, D.-H.; Kim, C.; Kim, K.S.; Dershowitz, W. A hybrid modeling approach to evaluate the groundwater flow system at the low- and intermediate-level radioactive waste disposal site in Gyeong-Ju, Korea. Hydrogeol. J. 2012, 20, 1341-1353. [CrossRef]

20. FracMan Technology Group. Interactive Discrete Feature Data Analysis, Geometric Modeling and Exploration Simulation, FracMan ${ }^{\circledR} 7$ User Documentation; Golder Associates Inc.: Hongkong, China, 2016.

21. Wang, X. Stereological Interpretation of Rock Fracture Traces on Borehole Walls and other Cylindrical Surfaces. Ph. D. Thesis, Virginia Polytechnic Institute and State University, Blacksburg, VA, USA, 2005.

(C) 2017 by the authors. Licensee MDPI, Basel, Switzerland. This article is an open access article distributed under the terms and conditions of the Creative Commons Attribution (CC BY) license (http://creativecommons.org/licenses/by/4.0/). 